\title{
An Investigation Into Design Criteria for Affordable Housing Supply
}

\author{
Abdul Lateef Olanrewaju, ${ }^{1, *}$, Lim Tat Lee ${ }^{1}$, Yeow Tan Seong ${ }^{1}$, Naoto Mine ${ }^{1}$, and Chai Teoh \\ Teng $^{1}$ \\ ${ }^{1}$ Faculty of Engineering and Green Technology, Universiti Tunku Abdul Rahman, 31900 Kampar, \\ Perak, Malaysia
}

\begin{abstract}
Affordable housing provision constitutes a very large scheme in any countries due to income distribution and national development. The supply of housing depends on many activities and processes. The purpose of the houses is to meet the requirement of the householders therefore design criteria must address the users' requirements. The establishment of the design criteria constitutes an important activity at the initial phase of the housing development. The design criteria are prepared by the design team in collaboration with many stakeholders especially the householders. Housinsg design criteria are the requirements that must be considered prior to construction of the housing. Lack of adequate information on the design criteria would lead to poor householders' satisfactions, increase in maintenance cost, abandonments and completed but not occupy housing. In Malaysia, many of these consequences are prevalent. However, while information on the house owners' requirements is inconclusive, this current research set out to investigate the design criteria of affordable housing. The increase in the affordable housing gap in Malaysia can be reduced if the designers have a comprehensive understanding of users' requirements and the design criteria. Through a cross sectional survey questionnaire, comprising 25 criteria, 7 criteria were found to be extremely critical. The Kaiser-Meyer-Olkin measure of sampling adequacy indicated that the strength of the relationships among variables was strong $(\mathrm{KMO}=0.716)$. Bartlett's test of sphericity, which tests the overall significance of all the correlations within the correlation matrix, was significant $\chi^{2}(325)=$ $1825.075, \mathrm{p}<0.001$ ), indicating the data were drawn from the same population and that the criteria were related.Sustainability considerations are now being considered by the providers of affordable housing. Deductively, the results lead to the conclusion that a major factor responsible for the poor homebuyers / homeo ccupiers dissatisfactions is the lack of considerations of the criteria that impact significantly on the buyers/occupiers choice. The findings are significant for developers, urban planners, banks, policy makers and the academia.
\end{abstract}

\footnotetext{
* Corresponding author: abdullateef.olanrewaju@ymail.com
} 


\section{Introduction}

The aim of the study that this paper reports part of is to analysis the supply and demand sides of affordable housing in Malaysia. This current study addresses itself to the design criteria in affordable housing. Olanrewaju, et al. (2016) noted the importance of examining the design criteria and constraints in affordable housing delivery, especially in the contexts of meeting the sustainability requirements [1]. However, the major difference between design criteria and design constraint is that while design criteria are requirements that must be met or take into account during the concept stage of the housing development by the developers/design team, the design constraints are restrictions that keep the design from being able to be the best design. It is noted that while there is information on housing determinants from the householders' perspectives, same cannot be claimed for the supply side. There is a dearth of information on the criteria on which designers based their decisions on housing development in general and to affordable housing in particular. It is likely that a major problem responsible for the imbalance in the supply and demand for affordable housing is the disparities between the design criteria and householders determinants in the affordable housing. If the design criteria and the homebuyers' requirements are not aligned, there are high tendencies that the increase in the housing abandonment and housing project abandonment will continue on abated. There will also be increased in maintenance and refurbishment costs. There will also be increased in home occupiers' dissatisfactions. Basic constraints in affordable housing include the price cap, locations, and quality specifications. For instance, affordable is generally seen to be cheap at least compare to standard houses. This is the problem that the developers have in affordable housing delivery. Hence, there is a constraint on how much the developer will charge for the affordable housing. But since the developers perceive it such, unfortunate though how this may be, there is limitation on the selection of material and components to use, and the quality of labour to employ. This will also affect the site selection. This explains why most affordable housing schemes are located away from the cities and with less social amenities and recreation facilities. This as well explains the poor performances of the affordable housing market. The option for affordable housing is always complicated by the design economic factors. Previously only size and quality standard is considered to influence the cost and the price of building [2]. However, it is now obvious that many different but interrelated criteria do not only influence the housing price, but determine the home buyers' buying/renting decision making. Ultimately, the various criteria have economic implications on home ownerships' or occupier-ships', long term plan. In Malaysia, many housing developments have failed to perform their design functions and too expensive to own and operate on account of their inabilities to consider the various Home buyers' and home users' requirements. Some investigations into the design management are therefore requiring critical investigations. The design criteria is a fusion of home owners requirements and design constraints, hence if the criteria can be identified and ranked and given the respective significance in the solving design problems it should be possible to provide value for money invested in accordance with the basic requirements. Such design will be the best design for the Home buyers' -"designed for home buyers"-Designing for the buyers is the only feasible solution to ensure Home buyers' satisfactions. Home buyers' satisfactions can be measured in different ways. But today, Home buyers' are concerned about many factors apart from the price of the unit/homes only. For instance, they are concerned about how much they spend on transportation, how far is their home to the workplaces, hospitals, markets, pay for utilities, access to recreations, maintenance and refurbishment costs, future modifications. It is imperative that all stakeholders and especially Home buyers' experiences are well considered in the development of the design criteria. However, it is important to realise that design management is not a pure science 
rather a social science, implying that knowledge of economics, sociology, psychology, laws, culture and politics will contribute significantly to the development of the design criteria. The purpose of this study was to obtain indications of the design issues obstructing the supply of affordable housing. For this reason, there is a need to be more careful over priorities, so to enhance the delivery of affordable housing supply. Therefore,this study investigates the critical design criteria in order to provide some suggestions and comments of the developers, policy maker and other relevant stakeholders in the delivery of affordable housing supply.

\section{Affordable housing and design management}

\subsection{Affordable housing supply and challenges}

To clarify, 'affordability' is an elastic word. At one end, a product is very affordable yet at the other end, it is [totally] unaffordable to the same group of buyers. This makes the issue of affordable housing somewhat complex to understand and explain. Thus 'affordable housing' is defined differently. Often, the term is used quite loosely to represent all types of housing developed by governments, its agencies or in partnership with the developers or social landlords. It will seem that the meaning of affordable housing is more easily defined than understood. The question then arises; at what point is the house that is not affordable to the same buyer was affordable earlier? Effectively, it means household income is a critical issue. Yet, obviously, affordable house carries different meaning to different people. However, to provide context for the definitions and interpretations, housing is 'affordable' if it rental cost, or mortgage repayment cost does not exceed 30 per cent of household income for households in the lowest 40 percent of the income distribution range [3]. For rental purposes, the $30 \%$ would include for utility bills, including for electricity, water, gas, sewage and garbage collection. In case of the mortgage, the amount includes the actual consideration, tax, insurance, utilities and maintenance. For instance, cumulatively, monthly expenditure for the rental is $26.7 \%$ of the household income [4].However, for the low and middle income earners is $35 \%$ [5]. In fact, 2014 inflation in the housing, water, electricity, gas and other fuels category increased to $3.4 \%$ (2013: $1.7 \%$ ), reflecting the upward adjustment in electricity tariffs and a broad-based increase in rents across different types of residential property [6]. Affordable housing is also defined in term of 'median multiplier' [6]. The Demographic compares the median house prices to the median household income to measure affordable housing based on annual international Housing Affordability Survey. The median income in Malaysia, 2016 was estimated at RM5720. As such contextualising the model into the Malaysia scenario, over three years will imply RM205, 000. As such the initial question that possible comes to mind, is what type of house will this amount be able to procure in the cities? The initial answer is none. This is amount is inadequate to buy a house in any of the major cities. This is because less than $50 \%$ the housing units built in the year 2015, had a price tag lower than RM 250,000 [7].

"One of Malaysia's longstanding development objectives is the provision of affordable housing for Malaysians in both rural and urban areas, with a focus on lower-income groups" [8]. Therefore, addressing the housing need for the low and middle income earners is very important as they form the basis of the national human capital. The provision of affordable and liveable social housing is very critical, particularly as the government is committed to encouraging greater home ownership among the 'bottom $40 \%$ households'. The intense pressure on the provision and maintenance of affordable housing are extreme. By 2020 , over $70 \%$ of Malaysians are expected to reside in the urban areas. Housing demand and requirements are expected to increase remarkably due to the rapidly growing in 
population, increase in foreigners (expatriate, students and tourists), migration, changing economic status of the citizens, changes in tastes, and dilapidation of the existing stock. At 2020, the population is estimated to reach 32.4 million. However, there is a high level of insufficiency in home supply. In fact, lack of affordable house is now a source of concern among Malaysians. To illustrate, available statistics show that Malaysia currently has $4,928,883$ representing an increase of $1.99 \%$ compared to 2014 (i.e. 4,831,791 actually) residences and of the total properties transacted $65 \%$ is residential and represents $50.4 \%$ in terms of value [9]. That, is home production is approximately 97,092 per annum. However home production has decrease compared to 2014 to 2013, where about 107,000 homes were provided. The plausible implication of these statistics is that there are about 6 persons per home. However, this is inadequate to achieve the above set objectives, countries like Australia and UK have on the average of 2.5 persons per home. Malaysia's growing population is increasing at a rate of about $1.7 \%$ a year, that is, in a year approximately 500,000 persons are added. To interpret, in one year, about 400, 000 persons will not have homes to live. This will lead to increase in the prices of home, or many will have to pay unaffordable prices to own or rent a home. Secondly, there will be an increase in maintenance demand. Because, a major factor that determine maintenance demand is the size of the households [10].Lack of affordable housing would lead to other social problems including traffic congestions, air pollution, accidents and urban sprawl. Hence, the existing housing stock would not be part of national gross fixed capital formation that is required in a country to stimulate and supports national development. Therefore policy makers need to take the supply-side imbalance into consideration to provide accommodations that are affordable in all respects. While incomes have increased by $101 \%$ since last ten, housing price has increased by corresponding $213 \%$ within the same periods. Table 1 contains the median income, since 1997.

Table 1.Household median income distributions (RM), 2006 - 2016 [11]

\begin{tabular}{|c|c|c|c|c|c|c|c|c|c|}
\hline Period & 1997 & 1999 & 2002 & 2004 & 2007 & 2009 & 2012 & 2014 & 2016 \\
\hline Malaysia & 1,724 & 1,704 & 2,049 & 2,211 & 2,552 & 2,841 & 3,626 & 4,585 & 5,720 \\
\hline
\end{tabular}

The government has introduced various schemes to increase home-ownership among Malaysians (e.g. Skim Rumah Pertamaku, Rumah Mesra Rakyat, and Perumahan Rakyat 1 Malaysia). The recently introduce overnight policy rate (OPR) introduced by the Bank Negara is also expected to have some positive impact on home ownerships since payment on the mortgage will be lower. The OPR will see reduction interests on the saving account and deposits are also expected to spur investors to consider investing their savings and deposits in the housing sector. However, with the recent global meltdown cause mainly the housing sector would mean investor will be very careful. Home-ownership was $63 \%$ in 2000; this dropped to 55\% in 2010 [11]. To interpret, there is an annual decline of about $1 \%$ in home-ownership. Home-ownership will thus be less than $50 \%$ by 2020 if the housing supply in not revised. While affordable housing is widening, issues pertaining to accessibility to workplaces, sizes, maintenance cost, incessant refurbishments and alterations, modifications, operations, remain major problems that require urgent attention. Many of the problems are related to the design of the housing. Quality degradation was highly due to no fixed design criteria has been set to housing development [12]. 


\subsection{Design management of affordable housing}

Housing delivery involves various sequential and sometimes overlapping processes and phases depending on the stakeholders and procurement strategy adopted. The RIBA 2013 Plan of Work identified 8 phases of the building delivery processes comprising of: strategic definition, preparation and brief, concept design, developed design, technical design, construction, handover \& close out and in use. The strategic definition, preparation and brief, concept designs are the most critical as they involve the project definition and design phases. Many professional parties involve in the design phases of housing delivery, notably architects, construction managers, quantity surveyors, services engineers and structural engineers. Often, based on the traditional procurement strategy, the architects provide the prime consultancy duties and roles. Irrespective of the procurement strategy and clients' characteristics, the importance of the strategic definition, briefing and design are strategic. It is in these phases that the housing needs, homebuyers' requirements, criteria and constraints of the housing scheme is defined, refined, and adopted. Once the phases are completed, the complete design is produced, and once the complete design is produced, about $70 \%$ of the construction cost has been determined. Unfortunately, except for individual private funded dwellings, the requirements of the home buyers are not conclusive at this stage. The future owners are not known. The requirements are only based on the design team's experiences. This often complicates the design management for public housing and housing provided by the developers. However, inadequacies analysis of the home buyers' requirements, and the housing constraints would lead to poor design criteria developments and this in turn leads to variations, cost overrun, delays, poor quality and other problems [17]. Ultimately, this will manifest in homeowners' dissatisfaction during the use phase of the housing. The dissatisfactions can come in terms of high maintenance cost, high utility bills, modification and refurbishment and location problems. The location problems may be due to lack of access to workplaces, children'd schools, recreation and amenities. Some homebuyers are dissatisfied if the house failed to promote social integration. The increase in awareness of pollution, waste, degradation and climate changes has also brought achieving sustainability requirements into the main focused, with many homeoweners, now questioning the sustainability credential of developers and contractors [1].

Design quality is a combination of functionality, building quality and impact of buildings. In most any project type, design quality can be uniquely defined for each facility. Yet, there are some general considerations that apply to most projects which are the efficient use of space, positive environmental impact, secure and safe facilities, energy efficient buildings, accessibility [14]. A good design involves balancing of community values, individual needs, aesthetic judgements, technical requirements. High design quality buildings ensure high productivity of the occupiers. Good design will provide value for money in terms of total cost and cost-in-use [15]. Aside from the great performance that quality design brings, better design housing would sell for higher values and at faster rates than others. Decisions made at the outset about size, form, materials, layout and aesthetics affect all the generations who reside in that house. The design criteria are the requirements that the design team uses as a benchmark to finalise the design. The design criteria are the product of design constraints, homebuyers' requirements, building codes and standards. The determinations of the design criteria affect developers' revenues and profits. The homebuyers' housing requirements on the other hand, are the criteria upon which buyers based their decisions on when completing their buying decisions. The criteria are extremely critical to them because they influence their satisfactions, rents, mortgage payment, maintenance costs, and transportation costs to workplaces, hospitals, market, schools, and other cost operations. It is very critical that both the homebuyers, housing requirements and design are congruently aligned.Therefore, decisions made during before and during the 
design phase are crucial to homeowners' satisfactions. Therefore, the design team and developer need to evaluate the design criteria for housing development to maximise their profit and increase homebuyers' satisfactions. The design criteria are strategic and should be finalised prior to the construction phase.

\section{Outline of resigning method}

In general, two types of questions exist in research design, namely the descriptive question and explanatory question. But this is sometime referred to as descriptive research and explanatory research respectively. The distinction between the two is pertinent here for a number of reasons. While the descriptive question is concerned with what is currently going into a 'system' the explanatory question addresses itself to giving insight into why that is going into a system. But, since the essence of this research is to incite the why question, this research is descriptive in nature. In other words, it aims to describe the design criteria that those concerns with affordable housing delivery based their decisions on. There is need to examine these criteria, there seems to be mismatch between users' requirements the affordable housing. This study consists of a literature review and survey. The questionnaires were administered to the respondents attending the ARCHIDEX (International Architecture, Interior Design \& Building Exhibition 2016) in the Kuala Lumpur Convention Centre. ARCHIDEX is help yearly and attending by architects and other members of the building design teams (i.e. engineers, quantity surveyors) in Malaysia and around the South East Asia countries. The ARCHIDEX 2016 was held on 20 July, 2016 to 23 July, 2016 and attended by more than 3000 delegates and exhibitors. This survey was conducted 23 (Saturday) July 2016. Altogether, 25 design criteria that are used in various housings across the world were addressed to respondents. The criteria were identified based on a literature review [i.e. 16-20] and the authors' experiences. Respondents were asked based on their current experience, to tick the criticality to which the criteria are considered in the design of affordable housing on a four continuum scale; where 1 denotes extremely critical, and 4 denotes not critical. Two and 3 are located in between. The criticality of the criteria is determined by the mean score. For interpretation, mean score of 1.00- 1.75 denotes extremely critical; $1.76-2.50$ denotes very critical; 2.51 3.25 denotes critical and $3.26-4.00$ denotes not critical. The mode technique was used to analyse the demography of the respondents. Mode was also used to determine the distribution of respondents with respect to the scales.

\section{Analysing the results of the survey}

\subsection{Analysis of respondents' profile}

All data gathered adopted Statistical Package for Science Social (SPSS) version 20 for analysis. Altogether 111 completed survey forms were returned and the results of which are contained tables 2, 3 and 4 and Fig. 1. More than 70\% of the respondents have obtained university degrees with more than $20 \%$ obtained either MSc. or Ph.D. (Table 2). Most of the respondents have either architectural or engineering background. Half of the respondents are either from building developer organisations or private architectural firms (Table3). Many also from the government sector as well as private quantity surveying firms and contractors organisations. Most help strategic positions in their organisations. About $75 \%$ have been working for more than five years and more than half have more than 10 years working experience (Fig. 1). More than $90 \%$ belong to various notable 
organisations in the Malaysian construction and housing industries (Table4). 41\% of respondents were the members of the Board of architects Malaysia while 28\% were members of the Board of Engineers Malaysia. 16\% and 7\% were members of the Board of Surveyors Malaysia and members of REHDA. On this basis, it is inferred that the respondents have adequate knowledge and skill have the capabilities and abilities to provide unbiased and valid information.

Table 2. Distribution of respondent's qualification

\begin{tabular}{|l|c|c|c|c|c|}
\hline Qualification & Diploma & BSc. & MSc/MBA & Ph.D. & Others \\
\hline Frequency (\%) & 24.3 & 51.4 & 19.8 & 1.8 & 2.7 \\
\hline
\end{tabular}

Table 3. Distribution of respondent's professional background

\begin{tabular}{|l|c|c|c|c|c|c|}
\hline $\begin{array}{l}\text { Professional } \\
\text { background }\end{array}$ & $\begin{array}{c}\text { Quantity } \\
\text { surveying }\end{array}$ & Engineering & Architecture & $\begin{array}{c}\text { Estate } \\
\text { management }\end{array}$ & $\begin{array}{c}\text { Town } \\
\text { planning }\end{array}$ & Others \\
\hline Frequency (\%) & 18.9 & 27.0 & 40.5 & 2.7 & 0.9 & 9.9 \\
\hline
\end{tabular}

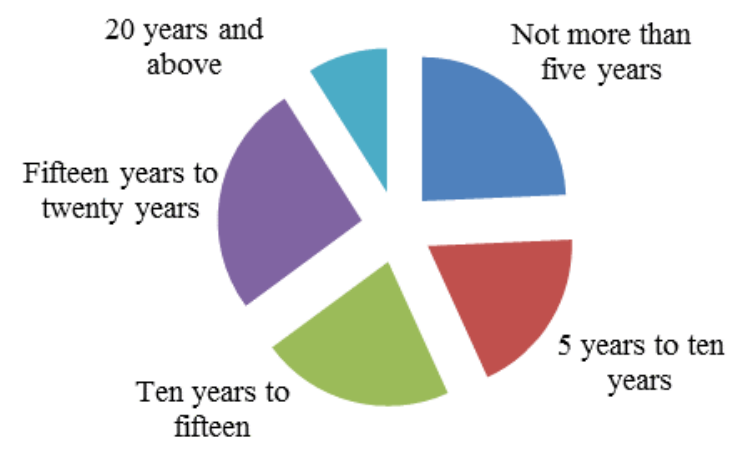

Fig. 1. Distribution of respondent's working experience

Table 4. Distribution of respondent's position

\begin{tabular}{|l|c|c|c|c|c|c|c|c|}
\hline Position & $\begin{array}{c}\text { Managing } \\
\text { director }\end{array}$ & Manager & $\begin{array}{c}\text { Project } \\
\text { manager }\end{array}$ & $\begin{array}{c}\text { Principal } \\
\text { partners }\end{array}$ & $\begin{array}{c}\text { Quantity } \\
\text { surveyor }\end{array}$ & Architect & Engineer & Others \\
\hline $\begin{array}{c}\text { Frequency } \\
\text { (\%) }\end{array}$ & 4.5 & 9.9 & 14.4 & 1.8 & 15.3 & 27.9 & 17.1 & 9.1 \\
\hline
\end{tabular}

\subsection{Analysis design criteria}

In order to test the strength of the criteria, both Crunch alpha reliability and Extraction communities were performed. From the results contain in Table 5 all the criteria were very reliable and highly valid except for maintenance cost that obtained a validity score slightly below the recommended score of 0.5 . The KMO also produced 0.716 signifying the lack of multicollinarity problems among the variable and that the respondents were drawn from those with similar experience. Since the Bartlett's Test of Sphericity is significant is confirmation that all the criteria are related. A one way t-test was conducted, the results of which were not reported here due to space constraint shows that all the criteria were significant $(\mathrm{p}=0.001)$, indicating that the population will probably measure all the critical criteria. Therefore, all the criteria are good indicators and appropriate for the aim of the 
study. Moving forwards, A K-S Test was conducted to tests the null hypothesis that the criteria are normally distributed. We find that the K-S Tests for most of the variable are not significant thus for most of the variables. In other words, the $\mathrm{H}_{0}$ is accepted. Therefore, the sample is a representative of the population. To determine the degree of criticality of each of the criteria, the mean score for each was computed and contain in Table 5. The mean scores range from 1.57 through 2.98 . While the safety of occupiers and security of property was the highest criterion and co-locating of outdoor facilities was the lowest criterion. The standard deviations also indicate that the disparities of measurement were suitable. Using the developed index scale in section 3 above, 7 criteria were extremely critical, 14 criteria were very critical and 8 criteria were measured critical. As may be seen none of the criteria obtained score up to 3.26 signifying that none of the 25 criteria was not critically considered in the design of affordable housing.In general, the results were consistent with our undisclosed hypothesis. It is not surprising that the respondent considered the safety of the building occupiers and security of their properties as major criteria in the affordable housing delivery. The increase in maintenance costs and future medications were also ranked as very critical. This is not unexpected. Researches have revealed that the operational costs of housing far outweigh the capital costs [21-22]. The quality of the environment also emerged as critical considerations. There are many cases of police reports on the behaviours of some owners of adjacent buildings. This is also related to location factor. For instance, if affordable housing is poorly located close to industrial areas, it will always affect the owners of buildings in the surrounding areas. However, the characters of the surrounding building turned out to be a very critical consideration by the design team/ developers in affordable housing supply. But issue relating to the location and surrounding areas of the affordable housing is quite complex. It may be that affordable housing is by policy not sited close to high end price for the negative perception that affordable housing has a negative implication on the property price. But while there are continuing oppositions to locating affordable housing in the cities, based on the review of seventeen studies that have attempted to measure the effect of affordable housing on property values it was found that the extent to which property values are lowered depends many factors [23]. The research indicates that the concentration of affordable housing is only a factor among many that affect property value.

Table 5. Distribution of descriptive statistics of the design criteria

\begin{tabular}{|l|c|c|c|c|}
\hline Criteria & $\begin{array}{c}\text { Validity } \\
\text { (communalities) }\end{array}$ & $\begin{array}{c}\text { Standard } \\
\text { deviation }\end{array}$ & Mean & Ranking \\
\hline $\begin{array}{l}\text { Safety \& security of occupier \& } \\
\text { property }\end{array}$ & 0.725 & 0.756 & 1.57 & 1 \\
\hline Maintenance costs & 0.498 & 0.824 & 1.58 & 2 \\
\hline Minimisation of noise \& nuisance & 0.836 & 0.776 & 1.60 & 3 \\
\hline Extent of required future modification & 0.726 & 0.849 & 1.69 & 4 \\
\hline Waste disposal & 0.717 & 0.783 & 1.69 & 5 \\
\hline $\begin{array}{l}\text { Character of the surrounding } \\
\text { buildings }\end{array}$ & 0.720 & 0.783 & 1.71 & 6 \\
\hline Element/component cost & 0.729 & 0.780 & 1.74 & 7 \\
\hline $\begin{array}{l}\text { Use products \& processes adapt to } \\
\text { climate change }\end{array}$ & 0.765 & 0.932 & 1.85 & 8 \\
\hline Water bills & 0.909 & 0.793 & 1.86 & 9 \\
\hline Energy bills & 0.773 & 0.800 & 1.87 & 10 \\
\hline Telephone bills & 0.904 & 0.850 & 1.88 & 11 \\
\hline Use of local labour & 0.784 & 1.058 & 1.92 & 12 \\
\hline Use of local materials & 0.796 & 1.041 & 1.92 & 13 \\
\hline
\end{tabular}




\begin{tabular}{|l|c|c|c|c|}
\hline $\begin{array}{l}\text { Use products \& processes that reduce } \\
\text { environmental impacts }\end{array}$ & 0.706 & 0.873 & 1.94 & 14 \\
\hline Variety in housing types & 0.643 & 0.991 & 2.19 & 15 \\
\hline A sense of place & 0.707 & 1.026 & 2.21 & 16 \\
\hline $\begin{array}{l}\text { Co-locating indoor activity areas in } \\
\text { the building }\end{array}$ & 0.711 & 0.937 & 2.43 & 17 \\
\hline Cater for senior citizens & 0.803 & 0.965 & 2.43 & 18 \\
\hline Connections to local transit service & 0.775 & 0.995 & 2.49 & 19 \\
\hline $\begin{array}{l}\text { Provide views to the outdoors from } \\
\text { indoor rooms }\end{array}$ & 0.882 & 1.048 & 2.49 & 20 \\
\hline $\begin{array}{l}\text { Access to recreation facilities by the } \\
\text { households }\end{array}$ & 0.870 & 1.013 & 2.52 & 21 \\
\hline Cater for disables & 0.850 & 0.939 & 2.54 & 22 \\
\hline $\begin{array}{l}\text { Locate stairs near the building main } \\
\text { entrance }\end{array}$ & 0.853 & 0.905 & 2.60 & 23 \\
\hline $\begin{array}{l}\text { Access to employment opportunities } \\
\text { of the household }\end{array}$ & 0.731 & 1.043 & 2.71 & 24 \\
\hline Co-locate outdoor elements & 0.531 & 0.949 & 2.98 & 25 \\
\hline
\end{tabular}

Kaiser-Meyer-Olkin Measure of Sampling Adequacy=716; Bartlett's Test of Sphericity= (325)1825.075, Sig. $=001$.

This current research founds that issue of waste disposal and cost of the building element was also very critical consideration by the design team. In other words, the design team considers waste management in the delivery of affordable housing. The design team also takes critical analysis of costs of elements in affordable delivery. In other words, the developers are probably very careful not to specify expensive materials and components for affordable housing delivery. This is very interesting because affordable housing is generally defined to mean cheap or low quality housing. Therefore, this finding is not surprising. In general, while some of the lower ranked criteria expected some were not expected. For instance, it is not surprising to find that accesses to employment opportunities of the household are and include rooftop gardens not critical, it is surprising to find that creation of quality neighbourhoods and co-locate outdoor elements were rated low. These findings are rather complicated and difficult to interpret. However, it is crucial that the quality of neighbourhood be considered in locating of affordable housing. This is to ensure social integration and community well-being. The qualities of the neighbourhood also include the availability of good health care facility, schools, and good roads, public parks, playing grounds, market and recreational amenities. But since the qualities of the neighbourhoods are not important, it will not be important to co-locate outdoor elements. It is only when the neighbourhoods are vibrant that sharing and using basic outdoor facilities like sport complex will be useful.

\section{Conclusion and recommendations to the design teams and developers}

This study has investigated the design criteria for affordable housing. Many criteria actually influence the design teams' decisions. Sustainability issues were revealed to be major determinants. However, ranking the criteria for housing development is a daunting task since development is distinct. Yet this information will guide the stakeholders, especially the design team about which design criteria are uniquely necessary for a development. The theoretical purpose is to ensure that homebuyers are satisfied with the homes and that the developers would be able to make 'sufficient' profit margin. In order to ensure 
homebuyers'satisfactions are maximised, it is very necessary that the house is designed for that purpose. The concept of 'design for homeowners' should be considered a practical possibility. This will ensure the completed homes meet the requirements of the buyers. To be strictly designed for the homeowners, housing ensures that little amount is spent on energy and waters used and little waste is generated/disposed. The house should be designed with a purpose or promoting occupants and community well-being and social integration. The house should be designed to be constructed and operated with reuse and recycle materials and components. Be readily maintained, refurbished and modified when required. Should use local materials and labour its construction and operation. The salvaged materials on demolition should be recycled and reuse and to be nontoxic. The occupiers will not pay more than required for transportation to workplaces, hospital, parks, and markets on account of them living in the house (location!). The house will not contribute to crime and vandalism rates in the neighbourhoods. And it should not destroy biodiversity. While, this study has been able to provide some preliminary information on the design issues of affordable housing in Malaysia, the readers should be aware that the design management, especially for affordable housing is very complex and sophisticated because various stakeholders, including contractors, urban planners, government, developers, housing associations, banks, service providers (for water, electricity, waste disposal) and insurances are involved. Often due to poor policy formulation and implementations and separation of roles it is difficult to identify the roles of each of the stakeholders. However, while this research has also been able to identify and prioritise the design criteria, there is the need to categorise these criteria for meaningful interpretation. Without categorising the criteria, decision making based ranking alone would not be rigorous. The combine impact of certain criteria will not be obvious and thus lead to poor performance. Therefore, a follow up article will fill this gap, using the factor analysis technique. Furthermore, further researches are useful to improve this research by 1) ways of increasing the sample size and 2) to validity the findings. There is no similar previous study to provide some reference for comparisons. It is equally important to investigate the requirements of the affordable households with respect to what specifically they expected from their houses. Our next research also seeks to develop a Critical Success Factor (CFS) for affordable housing policy makers, urban planners, housing developers, banks and relevant parties.

The material reported in this paper is fully supported by FRGS Grant under No. FRGS/1/2015/TK06/UTAR/02/2. The financial contribution is highly appreciated.

\section{References}

[1] A. Olanrewaju, S.T. Tan, L.T. Lee, M. F. Ayob, S.Ang, Investigating the compatibility of affordable housing with sustainability criteria: A conceptual framework, Proc. of Putrajaya International Built Environment, Technology and Engineering Conf., 228240, Bangi, Malaysia, (2016)

[2] A. Ashworth, Cost studies of buildings. 4th ed., Pearson Education Limited, Harlow, England, (2004)

[3] J. D, Dacquisto, R.D, Rodda, Housing impact analysis, U.S. Department of Housing and Urban Development, Government Printing Office, Washington, USA, (2006)

[4] Department of Statistics, The Malaysian economy in brief, Malaysia, (2014)

[5] Department of Statistics, Malaysia report on household expenditure survey, (2011), Retrieved on March 14, 2014 from http://www.statistics.gov.my/portal 
[6] Demographia 11th annual international housing affordability survey 2015 ratings for metropolitan market, (2015), Retrieved on March 5, 2015 from http://www.demographia.com/dhi.pdf

[7] National property information centre change value of transactions by price range for the prinsipal property sub-sectors, (2015), Retrieved on August 29, 2016 from http://napic.jpph.gov.my/portal

[8] Economic Planning Unit Prime Minister's Department, Tenth Malaysian Plan 200112015, , Putrajaya, Malaysia, (2010)

[9] National Property Information Centre, Summary of existing stock for residential, commercial, leisure and industrial property sub-sector as at Q1-Q4 2015 (2015). Retrieved on June 06, 2016 from http://napic.jpph.gov.my/portal

[10]A.A. Olanrewaju, Green maintenance management initiatives for university buildings, Built Environment Journal, 8(1), 17-24, (2011)

[11]Department of Statistics, Report on characteristics of household 2010: Population and housing census of Malaysia, Malaysia, (2014)

[12]E.M. Kamal, H. Hassan, A. Osmadi, Factors Influencing the housing price: Developers' perspective, Int. J. of Social, Behavioral, Educational, Economic, Business and Industrial Engineering, 10(5), 1603-1609, (2016)

[13]A. Musa, N. Mohd Tawil, A. Che Ani, B. Hassan, An analysis of the selection criteria in purchasing a house in Klang Valley towards the quality affordable housing, Life Science Journal, 12(3), 51-57, (2015)

[14]J. Neale, Improving housing quality - unlocking the market, Royal Institute of British Architects, London, (2009)

[15]A.M. Abdul Rahman, N.M.S. Al-Obaidi, K. Ismail, M.L. YokeMui, Rethinking the Malaysian affordable housing design typology in view of global warning considerations, J. of Sustainable Development, 6(7), 134-146, (2013)

[16]W.B. Olesen, The philosophy behind EN15251: Indoor environmental criteria for design and calculation of energy performance of buildings, Energy and Buildings, 7, 740-749, (2007)

[17]I. Sartori, A.GHestnes, Energy use in the life cycle of conventional and low-energy buildings: A review article, Energy and Buildings, 39(3), 249-257, (2007)

[18]S. Lang, Progress in energy-efficiency standards for residential buildings in China, Energy and Buildings, 36(12), 1191-1196, (2004)

[19]A. Kaklauskas, K.E. Zavadskas, K.E.S. Raslanas, Multivariant design and multiple criteria analysis of building refurbishments, Energy and Buildings, 37(4), 361-372, (2005)

[20]Housing Corporation, Design and quality standards: Strong communities, (2007), Retrieved on June 25, 2016 from https://www.gov.uk/government/publications/designand-quality-standards

[21]H.N. Ahuja, M.A. Walsh, Construction management and engineering: Successful methods in cost engineering, John Wiley, Canada, (1983)

[22]R. Flanagana, C. Jewell, Whole life appraisal for construction, Blackwell Publishing, Oxford, UK, (2005)

[23]T.M. Nguyen, Does affordable housing detrimentally affect property values. A review of the literature, J. of Planning Literature, 20(1), 15-26, (2005) 